\title{
Aetiology and treatment of acute bacterial infection of the external eye
}

\author{
D. V. SEAL, ${ }^{1}$ S. P. BARRETT, ${ }^{1}$ AND J. I. McGILL ${ }^{2}$ \\ From the ${ }^{1}$ Department of Microbiology, General Hospital, Southampton SO9 $4 X Y$, and \\ ${ }^{2}$ Southampton Eye Hospital, Southampton SO9 4XW
}

SUMMARY The microbial flora of 738 patients with acute bacterial conjunctivitis, corneal ulceration, blepharitis, dacryocystitis, and discharging sockets has been investigated. Staphylococcus aureus, Streptococcus pneumoniae, and Haemophilus influenzae were the main pathogens isolated. Str. viridans was associated with conjunctivitis in patients aged under 1 year. Moraxella sp. was isolated on only one occasion. Overall, $40 \%$ of specimens were associated with Staph. epidermidis or mixed skin flora, which also occurred with cultures of the normal eye. Clostridium welchii was isolated on 3 occasions but was not associated with bullae or gas gangrene. The least overall resistance, of $6 \%$, was to chloramphenicol, but no one antibiotic was effective against all pathogens. Gentamicin remains the antibiotic of choice for Pseudomonas aeruginosa infection.

The bacterial pathogens causing acute infection of the external eye, and their pattern of antibiotic sensitivity, have not been investigated recently in the United Kingdom, though they have been in the United States of America. ${ }^{1-3}$ Initial antibiotic treatment is on an arbitrary basis, often without preceding cultures, and is necessarily based on previous work. ${ }^{4}$ However, types of pathogenic bacteria are gradually changing, as are their antibiotic sensitivities, often resulting from plasmid transfer of inactivating enzymes. We carried out the present study to identify current pathogens in various acute conditions and to determine the most appropriate topical antibiotics with which to treat them.

\section{Materials and methods}

Patients were examined and clinical data recorded in the Casualty Department and Outpatient Clinic of Southampton Eye Hospital during January to December 1980 . Eyes were sampled by culturing conjunctivae or lid margins with sterile cotton-wool swabs, which were placed in Stuart's transport medium for transfer to the laboratory. Second swabs were collected for anaerobic culture and were placed directly into thioglycollate broth.

Aerobic culture was performed on chocolate agar in $5 \% \mathrm{CO}_{2}$ in air at $37^{\circ} \mathrm{C}$ for 48 hours; fluid enrichment

Correspondence to J. I. McGill, DPhil, FRCS, Southampton Eye Hospital, Wilton Avenue, Southampton SO9 4XW. medium was not used, as we wished to establish the predominant aerobic bacterial flora on a semiquantitative basis. Anerobic culture was carried out by incubating the thioglycollate broths for one week at $37^{\circ} \mathrm{C}$ and then subculturing them on to blood agar, supplemented with cystine and menadione, incubated anaerobically for $\mathbf{4 8}$ hours. Bacteria were identified by standard laboratory methods. ${ }^{5}$ Antibiotic sensitivity testing was performed by Stokes's control method with discs ${ }^{6}$ with tetracycline, neomycin, and gentamycin at $10 \mu \mathrm{g}$, chloramphenicol at $50 \mu \mathrm{g}$, and sulphacetamide at $100 \mu \mathrm{g}$.

Control cultures were taken from normal volunteer students and staff in the hospital.

\section{Results}

The percentage isolation rates of aerobic bacteria for each clinical condition are given as pure and mixed growths in Table 1. Isolation rates of anaerobic bacteria are similarly given in Table 2 . The percentage rates of antibiotic resistance for the various bacteria isolated as 'pure growths' above are listed in Table 3, together with the overall resistance rate to each antibiotic.

\section{Discussion}

Staphylococcus epidermidis was isolated in pure growth from $57 \%$ of normal conjunctival controls and 
Table 1 Aerobic bacterial growth

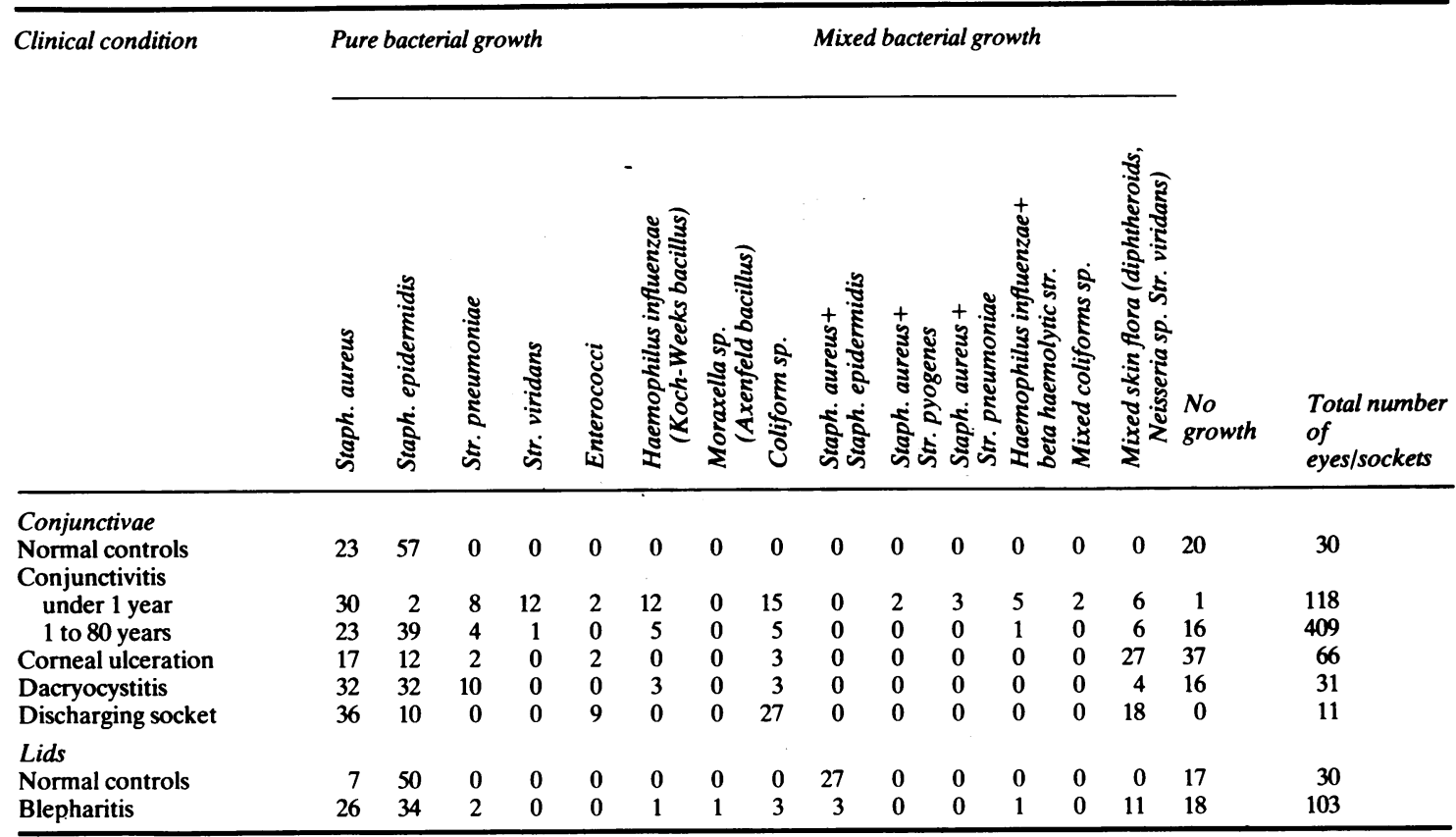

All figures given are percentages of the total for each group.

Table 2 Anaerobic bacterial growth

\begin{tabular}{llll}
\hline Clinical condition & $\begin{array}{l}\text { Clostridium } \\
\text { perfringens } \\
\text { (welchii) }\end{array}$ & $\begin{array}{l}\text { Anaerobic } \\
\text { cocci }\end{array}$ & $\begin{array}{l}\text { Total number } \\
\text { of eyes }\end{array}$ \\
\hline Conjunctivitis & & 0 & 7 \\
$\quad$ under 1 year & 0 & 2 & 103 \\
1 to 80 years & $1^{*}$ & 3 & 30 \\
Blepharitis & 0 & 0 & 27 \\
Dacryocystitis & $3^{*}$ & 3 & 28 \\
Corneal ulceration & $3^{*}$ & 0 & 3 \\
Discharging socket & 0 & &
\end{tabular}

All figures given are percentages of the total for each group. *Not associated with gas gangrene.

$50 \%$ of normal lid controls. Staph. aureus was found in $23 \%$ of normal conjunctival controls as a pure growth, but in $27 \%$ of normal lid controls as a mixed growth with Staph. epidermidis; it was, however, found predominantly as a pure growth in blepharitis. Perkins et al. ${ }^{1}$ found a Staph. epidermidis rate of $70 \%$ and a Staph. aureus rate of $13 \%$ in their normal conjunctival controls, which compared with other studies. The normal conjunctiva is thus usually colonised with Staph. aureus or epidermidis with a propensity for a pure growth of either, which needs to be considered when reviewing results of cultures of eye swabs. However, streptococci, haemophili, and coliforms were never isolated from normal conjunctivae and lids. While we failed to isolate anaerobic bacteria from our normal eyes, Perkins $e t$ $a l$. did so in a different fluid-enriched medium, finding Propionibacterium acnes in $44 \%$, peptostreptococci in $6 \%$, and Clostridium sp. in $1 \%$. It is known, however, that there is an anaerobic environment within the lacrimal duct, ${ }^{7}$ which is their probable source, rather than the conjunctiva, which has an aerobic environment.

We have previously investigated the bacterial flora in ophthalmia neonatorum ${ }^{8}$ and isolated predominantly Streptococcus viridans and Haemophilus influenzae ${ }^{9}$ when compared with controls, as well as Staph. aureus and Chlamydia trachomatis. We have now isolated similar pathogens, except chlamydiae, in children under 1 year old with acute conjunctivitis, as well as isolating Str. pneumoniae and coliform bacilli. However, we have not isolated Str. viridans from children over 1 year old or from adults with acute conjunctivitis, suggesting that it then ceases to be pathogenic to the conjunctiva. Mixed growths of staphylococci or haemophili with streptococci occurred in conjunctivitis only in children under 1 year. No cases of conjunctivitis were due to gonococci, meningococci, ${ }^{10}$ moraxella, ${ }^{11}$ or Aereomonas hydrophilia. ${ }^{12}$ However, Clostridium perfringens (welchii) was isolated from one case and 
Table 3 Antibiotic resistances of bacteria isolated in pure growth

\begin{tabular}{|c|c|c|c|c|c|c|}
\hline & Staph. aureus* & Streptococci & $\begin{array}{l}\text { Haemophilus } \\
\text { influenzae }\end{array}$ & $\begin{array}{l}\text { Coliform sp. inc. } \\
\text { Pseudomonas }\end{array}$ & $\begin{array}{l}\text { Clostridium } \\
\text { perfringens } \\
\text { (welchii) }\end{array}$ & $\begin{array}{l}\% \text { overall } \\
\text { resistance }\end{array}$ \\
\hline Chloramphenicol & 2 & 0 & 0 & $35^{\dagger}$ & 0 & $6 \ddagger$ \\
\hline Tetracycline & 5 & 7 & 0 & $31^{\dagger}$ & 0 & $9 \ddagger$ \\
\hline Gentamicin & 2 & 100 & 8 & 2 & 100 & 19 \\
\hline Neomycin & 3 & 100 & 6 & 6 & 100 & 20 \\
\hline Sulphafurazole & 12 & 8 & 39 & $42^{+}$ & 0 & $22 \ddagger$ \\
\hline Total numbers & 189 & 54 & 36 & 52 & 3 & 334 \\
\hline
\end{tabular}

All figures given are percentages of the total for each group.

*76\% resistant to penicillin.

$\$ 15 \%$ innate resistance of Pseudomonas aeruginosa.

$\$ 2 \cdot 4 \%$ innate resistance of Pseudomonas aeruginosa.

anaerobic cocci from another 2 , but there was no evidence of gas gangrene or anaerobic cellulitis.

The 27 cases of dacryocystitis all had a similar flora to conjunctivitis in the adult, though it may be primarily due to an actinomycete. ${ }^{7}$

We cultured 66 eyes with different types of corneal ulceration thought to be bacterial in origin, but 24 yielded no growth. In the remainder we had similar isolations to those from conjunctivitis in the adult, except Haemophilus influenzae, which was not isolated in association with corneal ulceration. No cases were due to beta haemolytic streptococci ${ }^{13}$ or Pseudomonas $\mathrm{sp}^{14}$ One case occurred from which Clostridium perfringens was isolated, but it was not associated with a bulbous lesion or a frothy coagulum. ${ }^{15}$

Discharging sockets were associated with Staphylococcus aureus, coliform spp., mixed skin flora, and enterococci. This is similar to the findings of Christensen and Fahmy. ${ }^{16}$

Both Staphylococcus aureus and epidermidis were isolated in pure growth from patients with blepharitis, but the significance of the Staph. epidermidis is doubtful, as it was present at a higher percentage in controls (50\% controls versus $34 \%$ patients). This was not the case with Staph. aureus ( $7 \%$ versus $26 \%$ ), whose isolation was thus significant $\left(x^{2}=5 \cdot 1, \quad 0.05>p>0.01\right)$. However, chronic staphylococcal blepharoconjunctivitis can be due to Staph. epidermidis in compromised hosts. ${ }^{17}$ Occasional isolates of other pathogens occurred, including Moraxella sp., which is usually associated with chronic blepharoconjunctivitis ${ }^{11}$ but can be isolated from chronic corneal ulcers. ${ }^{18}$ There were no further cases of Streptococcus pyogenes gangrene (necrotising fasciitis) of the lids. ${ }^{19}$

Chloramphenicol has remained the most effective antibiotic for topical treatment of infection of the external eye with the least overall resistance of $6 \%$, while tetracycline was the next most effective, with a comparative overall resistance of $9 \%$. Both chloramphenicol and tetracycline were less effective with coliform bacilli, for which the antíbiotic of choice is gentamicin. It has previously been suggested that chloramphenicol drops should be instilled hourly when treating conjunctivitis and that preparations also containing corticosteroid should not be used for treating superficial infections of the eye. ${ }^{4}$ Gentamicin remains the treatment of choice for Pseudomonas aeruginosa infection, but streptococci are resistant to it and contributed to the higher overall resistance. However, most ocular infections were caused by Haemophilus influenzae, Staphylococcus aureus, or Streptococcus pneumoniae or viridans, all of which are sensitive to chloramphenicol, which remains the most effective topical antibiotic for 'routine' use.

We thank the clinical staff at the Eye Hospital for examining the patients and collecting the swabs, and the technical staff of the laboratory for processing them. We thank our colleagues M. J. Absolon, I. H. Chisholm, A. R. Elkington, and C. B. Walker for allowing their patients to be included in this study. We thank Miss P. J. Stoffell for typing the manuscript, and also Mrs S. B. McGill.

\section{References}

1 Perkins RE, Kundsin RB, Pratt MV, Abrahamsen I, Leibowitz HM. Bacteriology of normal and infected conjunctiva. J Clin Microbiol 1975; 1: 147-9.

2 Jones DB, Robinson NM. Anaerobic ocular infections. Trans Am Acad Ophthalmol Otolaryngol 1977; 83: 309-30.

3 Brook I. Anaerobic and aerobic bacterial flora of acute conjunctivitis in children. Arch Ophthalmol 1980; 98: 833-5.

4 Editorial: The choice of antibacterial eye drops. Drugs Ther Bull 1972; 10: 45-7.

5 Cowan ST, Steel KJ. Manual for Identification of Medical Bacteria. 2nd ed. London: Cambridge University Press, 1974.

6 Stokes EJ, Waterworth PM. Antibiotic sensitivity testing. ACP Broadsheet 1972; 55.

7 Seal DV, McGill J, Flanagan D, Purrier B. Lacrimal canaliculitis due to Arachnia (Actinomyces) propionica. Br J Ophthalmol 1981; 65: 10-3. 
8 Pierce JM, Ward ME, Seal DV. Ophthalmia neonatorum in the 1980 ; incidence, aetiology, and treatment. Submitted for publication.

9 Kilian M, Mordhast C-M, Dawson CR, Lantrop H. The taxonomy of haemophili isolated from conjunctivae. Acta Pathol Microbiol Scand (B) 1976; 84: 132-8.

10 Brook I, Bateman B, Pettit TH. Meningococcal conjunctivitis. Arch Ophthalmol 1979; 97: 890-1.

11 Bijsterveld OP van. Acute conjunctivitis and moraxella. Am J Ophthalmol 1967; 63: 1702-5.

12 Smith JA. Ocular Aeromonas hydrophila. Am J Ophthalmol 1980; 89: 449-51.

$13 \mathrm{Kim} \mathrm{H-B}$, Ostler HB. Marginal corneal ulcer due to betastreptococcus. Arch Ophthalmol 1977; 95: 454-5.
14 Reid FR, Wood TO. Pseudomonas corneal ulcer. Arch Ophthalmol 1979; 97: 1640-1.

15 Stern GA, Hodes BL, Stock EL. Clostridium perfringens corneal ulcer. Arch Ophthalmol 1979; 97: 661-3.

16 Christensen JN, Fahmy JA. The bacterial flora of the conjunctival anophthalmic socket in glass prosthesis-carriers. Acto Ophthalmol (Kbh) 1974; 52: 801-9.

17 Smolin G, Okumoto M. Staphylococcal blepharitis Arch Ophthalmol 1977; 95: 812-6.

18 Cobo LM, Coster DJ, Peacock J. Moraxella keratitis in nonalcoholic population. Br J Ophthamol 1981; 65: 683-6.

19 Seal DV, Leppard BL, Widdowson J, McGill J, Tormey P. Necrotising fasciitis due to Streptococcus pyogenes. Br Med J 1980; 280: 1419-20. 